Akademik Siyer Dergisi / Journal of Academic Sirah

e-ISSN: $2687-5810$

Y11/ Year: 2, Say1 / Issue: 4, Sayfa / Page: 2-16

\title{
Hz. Peygamber ve Okçuluk
}

The Prophet and Archery

\section{Fatih Erkoçoğlu}

Prof. Dr., AYBÜ İnsan ve Toplum Bilimleri Fakültesi, Ortaçağ Tarihi Ana Bilim Dalı Prof. Dr., AYBÜ Faculty of Humanities and Social Sciences, Department of Medieval History Ankara / Turkey fatiherkocoglu@hotmail.com https:// orcid.org/0000-0002-5439-4530

\section{Makale Bilgisi / Article Information}

Makale Türü: Araştırma Makalesi / Article Type: Research Article

Geliş Tarihi: 13 Şubat 2021 / Date Received: 13 February 2021

Kabul Tarihi: 11 Mart 2021 / Date Accepted: 11 March 2021

Yayın Tarihi: 30 Haziran 2021 / Date Published: 30 June 2021

Yayın Sezonu: Haziran 2021 / Pub Date Season: June 2021

Atıf: Erkoçoğlu, Fatih. “Hz. Peygamber ve Okçuluk”. Akademik Siyer Dergisi 4 (Haziran 2021), 2-16. Citiation: Erkoçoğlu, Fatih. "The Prophet and Archery". Journal of Academic Sirah 4 (June 2021), 216. https://doi.org/10.47169/samer.879501

İntihal: Bu makale, iTenticate yazılımınca taranmıştır. İntihal tespit edilmemiştir. Plagiarism: This article has been scanned by iTenticate. No plagiarism detected. web: http://dergipark.gov.tr/samer e-mail: akademiksiyerdergisi@ksu.edu.tr

Copyright $($ P Published by KSÜ Siyer-i Nebi Araştırmaları Uygulama ve Araştırma Merkezi KSU Sirah Researches Application and Research Center

Kahramanmaraş 46100 Turkey

Bütün hakları saklıdır. / All right reserved. 


\title{
Öz
}

Hz. Peygamber Arap Yarımadası'nın en önemli kenti olan Mekke'de İslâm dinini tebliğe başladıktan sonra, hicret ettiği Medine'de yeni bir toplum ve devlet tesis etti. $\mathrm{O}$, hicretten kısa süre sonra Medine'nin çevresine seriyyeler göndermiş, bazen de bizzat kendi komutasında gazve dediğimiz askeri seferler düzenlemişti. Zira Mekkeli Müşrikler kendisini ve küçük toplumunu, büyük bir tehdit olarak görmeye başlamışlardı. Hz. Muhammed (sav) de Medine'de bir taraftan şehrin savunması için ittifaklar oluştururken, diğer taraftan da küçük Müslüman toplumunu askeri faaliyetlere hazırlamaya başlamıştı. İşte bu bağlamda bilhassa kaynaklarımıza yansımış olan okçuluğa (atıclık) dair bazı hadisler söz konusudur. Zikredilen bu hadislerden $\mathrm{Hz}$. Peygamber'in ok ve yay kullanımına büyük önem verdiği fark edilmektedir. Bu makalede $\mathrm{Hz}$. Peygamber'in hadisleri doğrultusunda, dönemindeki okçuluğa dair bazı tespitlere ve bilhassa bu dönemdeki seriyye ve gazvelerde okçulukla ilgili önemli görülen hususiyetler değerlendirilmeye çalışılacaktır.

Anahtar Kelimeler: Siyer, Hz. Muhammed, Medine, Savaş, Okçuluk.

\begin{abstract}
After the Prophet started preaching the religion of Islam in Mecca, the most important city of the Arabian peninsula, he established a new society and state in Medina, where he migrated. Shortly after the Hijra (migration to Medina), he organized military operations around Medinah, called sariyya, sometimes he organized military expeditions, which we call ghazwa, under his own command. Then the Makkan polytheists began to see himself and his small community as a great threat. While Muhammad (pbuh) also formed alliances to defend the city in Medina, he also started to prepare the small Muslim community for military activities. In this context, there are a number of hadiths about archery, which are particularly reflected in our sources. It is noticed from these hadiths that the Prophet attached great importance to the use of bow and arrow. In this article, in accordance with the hadiths of the Prophet, some determinations about archery in the period and especially the important aspects of archery in the sariyyas and maghāzī in this period will be tried to be mentioned.
\end{abstract}

Keywords: Sirah, Muhammad, Medina, War, Archery. 


\section{GİRIŞ}

Tarih öncesi dönemlerden beri savaş ve av aleti olarak kullanılan ok ve yay eski Mezopotamya'da bir güç sembolu olarak görülmektedir. Sümerlilerin kozmolojisini temel alan Enuma Eliş (Vaktiyle Yukarıda) Babil Yaradılış Destanı'nda bütün Mezopotamya tanrıları arasında en yüce, en büyük konuma gelen Tanrı Marduk'un savaşmak için kendisine bir ok ve yay yaptığı, bunlarla Tanrı Tiamat'ı kalbinden vurarak hayatına son verdiği belirtilir. Ardından da Tiamat'ın dev gövdesini ikiye bölerek evreni yarattığı, gövdenin bir yarısıyla göğü, öteki yarısı ile de yeri yarattığı nakledilir. ${ }^{1}$

İnsanın ok ve yayı kullanması ise Hz. Âdem ile başlatılmıştır. Onun ektiği tohumları yiyen kargaları, Cebrâil'in kendisine getirdiği ve kullanmayı öğrettiği ok ve yayla kovduğu aktarılmaktadır. ${ }^{2}$

Zaman içerisinde pek çok topluluk ok ve yayı avcılık ve askeri amaçlarla kullandılar. M.Ö. 2025612 yılları arasında varlıklarını sürdüren Asurlu birliklerin tanımlamaları, kullanmış oldukları silahlara ve teçhizatlara göre "ok taşıyan" veya "okçu asker" şeklinde yapılmıştır. Asur rölyeflerinde piyadeler okçu ve sapancı olarak iki kategoride resmedilmiştir. Asur okçularının oklarının temrenlerinin demir olması, savaşın kaderini belirlemede önemli rol oynadığı gibi onların kendi dönemlerinin en önemli vurucu güçleri olduğu ifade edilmektedir. Savaşlarda ve bilhassa kale kuşatmalarında kapı ve sair ahşap malzemeyi yakmak için yanıcı oklar bile bu dönemlerde kullaniliyordu. ${ }^{3}$

Antik Mısır'da da okçuluk ve avcılık önemli idi. Mısırlıların avcılığı bir sportif faaliyet olarak gerçekleştiren ilk topluluk olduğu ifade edilmektedir. Böylece okçuluk Misır'da popüler bir eğlence tarzı olarak ön plana çıkmıştı. ${ }^{4}$

Ok ve yay, bozkır süvarilerine dayalı orduları olan tüm topluluklarda en önde gelen silahlardı. ${ }^{5}$ Orta Asya ve Karadeniz'in kuzeyinde hakim olan İskit toplulukları tamamıla süvarilere dayanan ordulara sahip oldular. Bundan dolayı Parthlar devrinden itibaren İran ordularının da Akdeniz geleneğinden uzaklaşarak salt süvariye (okçu süvariye) dayalı bir sistem geliştirdikleri görülmektedir. Partlar'ın mirasçıları olan Sâsânîler de Saka-İskit, Sarmat, Kuşhan, Hun kabilelerinden edindikleri müttefikler ile kalabalık süvari kıtaları kurmuşlardı. Ne var ki zamanla okçu süvarileri geri plana çekip ağır zırhlı, mızraklı süvari birlikleri oluşturmaya başladılar. Buna karşılık Sâsânîler, piyadeler içerisinde okçu piyade, mızrak atıcılar ve sapancılar gibi alt birimlere de yer vermişlerdi. ${ }^{6}$

${ }^{1}$ Jean Bottero - Samuel Noah Kramer, Mezopotamya Mitolojisi, çev. Alp Tümertekin (İstanbul: İş Bankası Kültür Yay., 2017), 717, 722, 723 .

2 Nebi Bozkurt, "Ok", Türkiye Diyanet Vakfi İslâm Ansiklopedisi (İstanbul: TDV Yay., 2007), 33/333.

${ }^{3}$ L. Gürkan Gökçek - Faruk Akyüz, "Asur Ordusu", Tarih Araştırmaları Dergisi 32/54 (2013), 47.

${ }^{4}$ Feyzullah Koca, "Antik Mısır'da Avcılık, Binicilik, Okçuluk ve Görsellerin Yorumlamaları", Uluslararası Sosyal Araştırmalar Dergisi 11/59 (2018), 1496.

${ }_{5}^{5}$ Ulaş Töre Sivrioğlu, "Sâsânîlerde Askeri Teşkilat, Silah Teknolojisi ve Savaş Stratejileri", Turkish Studies 8/5 (2013), 684.

${ }^{6}$ Sivrioğlu, "Sâsânîlerde Askeri Teşkilat", 681-683. 
Doğu Roma ise Tuna kıyılarındaki çok çeşitli halklardan ordularına asker devşiriyordu. Suriye bozkırları ise müttefik Arap kabilelerine bırakılmıştı. Doğu Roma, Ostrogotları yaya okçular olarak ordularında istihdam etmişti. Okçuların arkasında onları koruyan seçkin süvariler bulunurdu. Ayrıca atlı okçular da savaşlarda kullanılmaya başlanmış hatta giderek orduların ana askeri unsurları olarak öne çıkmışlardı. Heraklios (M. S. 610-641) iktidarı ele geçirdiğinde dağınık ve başsız, fakat çok kalabalık Roma birliklerini teçhiz etmiş ve yeniden düzenlemişti. Ne var ki bu ordunun vurucu gücünü oluşturan atlı okçuların eksikliği söz konusu idi.7 Zaten o Sâsânîler'in elinden kurtardığı Mısır ve Suriye'yi belki de bu durumun da katkısı ile çok kısa süre sonra Müslüman Araplara birakmak zorunda kaldı.

En eski zamandan İslâm'ın doğduğu asra kadar, Arap Yarımadası'nın çevresinde varlıklarını sürdüren devletlerde okçuluğun önemli bir yer tuttuğu fark edilmektedir. Bu makalede Hz. Muhammed (sav) döneminde ok ve yayın kullanımının kaynaklarımıza nasıl yansıdığı ele alınacak olup nihayetinde bu dönemde ok ve yayın belirgin bir şekilde kullanıldığ sunulmaya çalışılacaktır.

\section{HZ. PEYGAMBER VE OKÇULUK}

Okçuluk ve nişancılık yukarıda kısa hatlarla belirttiğimiz üzere hemen her toplumda karşılık bulmuş ve okçular, başta avcılık olmak üzere çeşitli alanlarda önemli işlev görmüşler ve askeri faaliyetlerde orduların en önemli vurucu gücünü oluşturmuşlardır. Hz. Peygamber döneminde okçuluk bahsiyle ilgili olarak bu çalışmaya başladığımızda bilhassa hadis metinlerinde okçuluğun öneminin mühim bir şekilde vurgulandığı hemen dikkatimizi çekti. Tabii olarak bu malzemenin, bilhassa Medine döneminde yoğunlaştığı fark edilmektedir. Zira Hz. Peygamber'in Mekke'deki yaşamında henüz 20 yaşında iken amcalarıyla birlikte katıldığı kabul edilen Dördüncü Ficâr Savaşı'nın dışında herhangi bir askeri faaliyete katıldığına dair elimizde sahih bir rivayet bulunmamaktadır.

İslâm öncesinde Arap kabileleri arasında çeşitli sebeplerle sık sık savaşlar ortaya çıkıyordu. Bu savaşlardan dört tanesi kötülük yapmanın ve kan dökmenin yasak olduğu haram aylarda yapıldığı için Ficâr Savaşları olarak anılmıştır. Bu savaşta Kureyş ve Kinâne ${ }^{8}$ kabileleri, Kays Aylân ve müttefikleriyle karşı karşıya gelmiş, bu savaşta Kureyş kabileleri ayrı ayrı birlikler halinde savaşmışlardı. Benî Hâşim'in komutanlığını Hz. Peygamber'in amcası Zübeyr b. Abdilmuttalib yapmış ve bu savaşı Kureyş kazanmıştı.

Hz. Muhammed'in de amcalarıyla birlikte Kureyş'in saflarında bu savaşa katıldığı, fakat savaşmadığı sadece amcalarına ait eşyaları koruduğu, atılan okları kalkanlarla karşılayıp toplayarak onlara vermekle yetindiğinin söylendiği gibi, ok attığı ve bundan dolayı da pişman olmadığını ifade ettiği de nakledilmektedir. ${ }^{9}$

7 David Nicolle, Doğu Roma Orduları (M.S. 306-886), çev. Buket Bayrı (İstanbul: Türkiye İş Bankası Kültür Yay., 2013), 27-33.

8 Adnânîler'e mensup büyük bir Arap kabilesi olan Kinâne kabilesinin adı ca'be gibi ok kılıfı, tirkeş anlamlarına gelmektedir (Çoğulu ise Kenâin'dir).

${ }^{9}$ Muhammed b. Sa'd b. ez-Zührî, Tabakâtu'l-kübrâ (Beyrut: y.y., 1996) 1-2/60, 61. Ayrıca bk. İbrahim Sarıçam, Hz. Muhammed'in Evrensel Mesajı (Ankara: DİB Yay., 2003), 66-67. 
Hz. Muhammed'in Mekke'den Medine'ye hicreti, cemaat yapısından devlet yapısına geçiş aşamasını oluşturmaktadır. Zira o, zaten canına kastedildiği için Mekke'den ayrılmak zorunda kalmıştı. Mekke döneminde nazil olan ayetlerde Hz. Peygamber'e ve Müslümanlara sürekli sabır tavsiye ediliyordu. Ne var ki onun Medine'ye hicreti ve burada önemli bir askeri güce dönüşmesi, Kureyş için büyük bir tehdit olarak görülmüş ve bu durum onlar tarafından şiddetini artıran bir şekilde saldırıya dönüşen tepkiyle karşılanmaya başlamıştı. Nihayetinde Hz. Peygamber'e İslâm davasını güvence altına almak, meşru müdafa adına Medine'yi yabancı saldırılarından korumak maksadıyla Allah tarafından savaş izni verilmişti;

"Kendilerine savaş açılan Müslümanlara, zulme uğramaları sebebiyle cihad için izin verildi. Şüphe yok ki Allah'ın onlara yardım etmeğe gücü yeter. Onlar haksız yere, sırf "Rabbimiz Allah'tır" demelerinden dolayı yurtlarından çıkarılmış kimselerdir. Ĕğer Allah'ın, insanların bir kısmını bir kısmıyla defetmesi olmasaydı, içlerinde Allah'ın adı çok anılan manastırlar, kiliseler, havralar ve mescitler muhakkak yerle bir edilirdi. Şüphesiz ki Allah, kendi dinine yardım edene mutlaka yardım eder. Şüphesiz ki Allah çok kuvvetlidir, mutlak güç sahibidir. Onlar öyle kimselerdir ki, şayet kendilerine yeryüzünde imkan ve iktidar versek, namazı dosdoğru kılar, zekatı verir, iyiliği emreder ve kötülü̈̆̈̈ yasaklarlar. Bütün işlerin akıbeti Allah'a aittir."10

Hz. Peygamber döneminde, görevlendirdiği komutanların seriyyeleri ile bizzat kendisinin kumanda ettiği bir dizi gazve gerçekleştirildi. Toplamda otuz beş ila altmış altı arasında çeşitli sayıda seriyyeler yapılmış iken, gazvelerin sadece dokuz tanesinde çatışma vuku bulduğu belirtilmelidir.

Büyük Bedir Gazvesi öncesinde, Kureyş tehdidini önleyebilmek, Medine yakınından geçen Suriye ticaret yolunu onlara kapamak ve ekonomik ambargo uygulamak amaciyla stratejik önemi olan bölgelere yönelik dört seriyye ve dört gazve tertip edildi. Bu düzenlenen seriyye ve gazvelerde, hicretten 17 ay sonra gerçekleştirilen Batn-ı Nahle seriyyesinin dışında herhangi bir çarpışma yaşanmamıştı. Belki de bu seriyye ve gazvelere çıkıldığı ölçüde Hz. Peygamber, sahip olduğu küçük ordusunun askeri yeteneklerini yavaş yavaş öğrenmeye başlamıştı. Zira her ne kadar Müslüman Araplar silah kullanmayı bilseler ve muhtelif çatışmalara girerek tecrübe kazanmış olsalar da (Evs ve Hazrec'in yakın zamanda aralarında yaptıkları Buas Savaşı bu bağlamda önemlidir) Hz. Peygamber'in yönetiminde ilk defa askeri faaliyetlere girişmişlerdi. Belki de bu süreç zarfında küçük ordusunun askeri kapasitesini öğrenen $\mathrm{Hz}$. Muhammed böylece onların bu kapasitelerini artırabilmek için de bir kısım faaliyete girişmiş olmalıydı. İşte burada özellikle kaynaklarımızda okçulukla ilgili olarak zikredilen hadislerin varlığı oldukça dikkat çekicidir. Zira okçulukla ilgili olabilen malzemenin Medine'deki hayatın her alanını kapsayacak şekilde verilmesi özellikle bunu göstermektedir.

Eski Ahid'in Tekvin bahsinde Hz. Peygamber'in büyük dedesi Hz. İsmail'in bir okçu olduğu “Ve Allah çocukla beraberdi, ve o büyüdü; ve çölde oturdu, ve büyüyerek okçu oldu..."11 ifadesiyle yer

\footnotetext{
10 el-Hac 22/39-41.

${ }^{11}$ Kitabı Mukaddes, Tek. 21:20.
} 
almaktadır. Hz. Peygamber'in de ok atan ashabını dedelerine özenmeleri için teşvik etmeye başlamış olduğu fark edilmektedir. ${ }^{12}$

Hicretin 2. (624) yılında vuku bulan Bedir Savaşı'nın başlamasından kısa bir süre önce Hz. Peygamber'in ordusuna, izleyeceği savaş stratejisi ile ilgili olarak verdiği talimat ise okçuluğun önemini vurgular niteliktedir. "Saflarınızı bırakıp ayrılmayınız. Hiçbir yere kımıldamayıp yerinizde kalınız. Ben emir vermedikçe savaşa başlamayınız. Oklarınızı düşman size yaklaşmadan kullanıp (ok menzilinize girmeden) israf etmeyiniz. Düşman kalkanın açtığı zaman okunuzu atınız. Düşman iyice yaklaşınca elinizle taş atınız. Daha da yaklaşırsa mızrak ve kargılarınızı kullanınız. Kılıç en sonra, düşman ile göğ̈̈s göğ üse gelindiği zaman kullanılacaktır".13

Anlatıldığı üzere Hz. Peygamber'in safları çok sağlam olacak şekilde düzenleyerek ${ }^{14}$ Bedir kuyularında bir saf savaşı yaptığı anlaşılmaktadır. Ayrıca okların israf edilmemesi ve düşmanın kalkanını açtıktan sonra fırlatılmasını istemesi, onun savaşlardaki okçuların öneminin farkında olduğu anlamina geliyordu. Hadis metinlerine yansıyan Medine'de ok ve yay kullanımı üzerine söyledikleri de bunu destekler niteliktedir.

Hz. Peygamber Bedir Savaşı'ndan sonra nâzil olan Enfâl süresinde geçen "Onlara karşı gücünüz yettiği kadar kuvvet ve cihad için bağlanıp beslenen atlar hazırlayın"15 ayetindeki kuvvetin atmak olduğunu, üç defa vurgulayarak ifade etmiştir. ${ }^{16}$ Atmak tabirinin hadis metinlerinde ok ve yay için kullanıldığı burada belirtilmelidir. Hz. Peygamber'in bu vurgusunun, daha önceki seriyye ve gazveler ile bilhassa Bedir Savaşı'ndaki tecrübeden kaynaklandığı anlaşılmaktadır.

Bu bağlamda ele alınabilecek hadisler ise kaynaklarımızda muhtelif yerlerde zikredilmektedir. Bir rivayete göre Hz. Peygamber'in bir okun üç kişinin cennete girmesine vesile olacağını (yapan, atan, atılmak üzere veren) söylediği nakledilmektedir. Aslında burada ok ve yay silahını kullananın dışında, tabi olarak ok ve yay yapımında çalışanların da önemine vurgu yapıldığı fark edilmektedir. $\mathrm{Bu}$ rivayetin devamında ise onun, atıcılığın kendisine binicilikten daha sevimli geldiğini söylediği belirtilmektedir.17 Zira o dönemde çocukların ya da yetişkinlerin bir şekilde ata veya deveye binebileceği anlaşılmakta olup, "...Sizden biriniz oklarıyla oynamaktan aciz kalmasın" denilerek ok atmanın belirli bir beceri gerektirdiğinin, ok atmaktaki maharetin ise ancak fazla talim yaparak yani

${ }^{12}$ Zeynüddin Ahmed b. Ahmed ez-Zebîdî, Sahîh-i Buhârî Muhtasarn (Tecrid-i Sarîh Tercemesi ve Şerhi), çev. Ahmed Naim (Ankara: y.y., 1983), 8/331-332.

${ }^{13}$ Bk. Ebû Abdullah Muhammed b. Ömer el-Vâkıdî, Hz. Peygamber'in Savaşları (Kitâbü'l-Meğâzî), çev. Musa K. Yılmaz (İstanbul: İlk Harf Yay., 2007), 1/115; Ebû Muhammed Abdülmelik b. Hişâm, es-Sîretü'n-Nebeviyye, tlk. Ömer Abdüsselâm Tedmûrî (Beyrut: y.y., 1993), 2/268; Muhammed Hamidullah, Hz. Peygamber'in Savaşları (İstanbul: y.y., 1991), 69.

14 İbn Sa'd, Hz. Peygamber'in eline aldığı bir okla safları düzelttiğini nakletmektedir. Bk. Muhammed b. Sad b. ez-Zührî, Kitâbü't-Tabakâti'l-Kebîr, Tabakât, Resûlullah'ın Kutlu Sîreti, çev. Musa Kazım Yılmaz vd. (İstanbul: Siyer Yay., 2015), 2/12.

15 el-Enfâl 8/60.

${ }^{16}$ Ebû'l-Hüseyin Müslim b. el-Haccâc b. Müslim el-Kuşeyrî, Sahîh, thk. Muhammed Fuâd Abdülbakî (İstanbul: y.y., 1992), "İmâre", 167.

17 Ebû Dâvud Süleyman b. el-Eş'as, Sünen, haz. Bedrettin Çetiner (İstanbul: y.y., 1992), "Cihâd", 23; Ebû Abdurrahman Ahmed b. Şu'ayb b. Ali en-Nesâ̂,, Sünen, haz. Bedrettin Çetiner (İstanbul: y.y., 1992), “Hayl”, 8; Ebû Muhammed Abdullah ed-Dârimî, Sünen, tlk. es-Seyyid Abdullah Hâşim Yemânî el-Medenî, (İstanbul: y.y., 1992), "Cihâd", 14. 
çalışmakla olacağının hatırlatıldığı görülmektedir. ${ }^{18}$ Hadiste geçen "oklarıyla oynamak" tabirinden kastedilenin ise atış temrini (devamlı talim yapılması) olduğu açıktır. İyi bir şekilde öğrenildikten sonra okçuluğun unutulmasının ise hoş karşılanmadığı, bunu terk edenin de kendilerinden olmadığı ya da kendilerine isyan ettiği hususuyla bağlantılı olarak verildiği anlaşılmaktadır. ${ }^{19}$

Başka bir rivayette ise Hz. Peygamber'in atıcılığı (okçuluk), at terbiyesini ve kişinin eşine ilgi ve alaka göstermesini en meşru eğlenceler arasında değerlendirdiği görülmektedir. ${ }^{20}$ Buna göre Müslüman, dinlenmeye, eğlenmeye ayıracağı boş vaktini atıcılık temrini yapmakla geçirmelidir. Böylece o kişi faydalı bir meşguliyetle uğraşmış olmanın dışında bu dönemde hem savaş için hazırlık yapmış hem de avcılıkla ailesinin geçimini sağlamış oluyordu. Ayrıca Hz. Muhammed'in sahabesine yaylarını kuşanıp kederlerini onunla dağıtmalarını öğütlemesinden de okçululuğun insan tabiatına iyi geldiği anlaşılmaktadır. ${ }^{21}$ Gerçekte bugün spor kabilinden değerlendirilebilecek bir husus olarak, canlı olmaksızın herhangi bir hedefe yönelik atışların bile, insanı dinlendirmekte olduğunu, insanı yaptığı işe yoğunlaştırdığını yay çekip ok atan birisi olarak söyleyebilirim.

Hz. Peygamber'in diğer taraftan deve, at ve ok atma (huf, hâfir ve nasal) yarışlarını meşru gördüğü eğlenceler arasında zikrettiği hadis metinlerinde kayıtlıdır.22 Burada ele alınan nasal, özellikle ok ve mızrak gibi delici aletlerin demir kısmına denilmekte olup bundan kastın ok yarış1 olduğu açıtır. Diğer hususlar ile okçuluğun teşviki bu dönemin şartlarında önemli görülmektedir. Henüz Müslüman ordusunun muvazzaf askerlerden oluşmadığı bir dönemde böylece hemen herkesin aynı zamanda iyi birer okçu, birer savaşçı olmasının istenildiği ortadadır.

Hz. Peygamber zamanında çocukların da ok talimi için ucunda temren yerine çamur toprağı veya çekirdeği çıkarılmış hurma bulunan küçük oklar kullandıkları nakledilmektedir. Bu oklara "cümmâh" veya "cübbâh" denilirdi ve bu oklarla çocuklar bazen kuş avlarlardı. ${ }^{23}$ Ayrıca çocukların canlı hedeflere nişan almalarının ise "Kendisinde ruh olan hiçbir canlıya (atışlarnnza) hedef ittihaz edinmeyin" ifadesiyle Hz. Peygamber tarafından hoş görülmediği zikredilmelidir. Bu şekildeki atışların sadece çocuklar tarafından yapılmadığı, zikredilen hadislerden anlaşılmaktadır. İbn Ömer'den gelen rivayete göre tavuk, keçi gibi bazı hayvanları hedef olarak koyup bunlara ok atanları Hz. Peygamber'in lanetlediği nakledilmektedir. ${ }^{24}$ Bu şekilde öldürülen hayvanın etinin ise yenilmemesi gerektiği belirtilmektedir.

Hz. Peygamber dönemi Medine'sinde okçuluk bu kadar vurgulanırken, okla alakalı olarak ortaya çıkabilecek ya da çıkan bazı toplumsal sorunların da çözüm yoluna gidildiğini, rivayet edilen bazı hadislerden anlamaktayız. Hz. Peygamber'in "Müslüman'a silah veya kılıç çeken yahut ok atan bizden değildir" dediği, yine bir başka hadiste bir kimsenin -elinde gerilmiş yaydaki ok gibi- bir silahla bir başkasına doğru gelmemesi, şeytanın onu bir anda elinden çıkarıp o şahsın ölümüne,

\footnotetext{
18 Müslim, “İmare”, 168.

19 Müslim, "İmâre”, 169.

${ }^{20}$ Ebû Dâvud, "Cihâd", 23; Nesâî, "Hayl”, 8; Dârimî, "Cihâd”, 14.

${ }^{21}$ Nebi Bozkurt, Hadiste Folklor ve Ĕ̆lence (İstanbul: İFAV Yay., 1997), 116.

22 Ebû Dâvud, "Cihâd”, 60; Ebû İsa Muhammed b. İsa b. Sevre et-Tirmizî. Sünen. haz. Bedrettin Çetiner. 4 Cilt. İstanbul: y.y., 1992. "Cihâd", 22; Nesâî, "Hayl", 14.

23 Bozkurt, Hadiste Folklor ve Ĕ̆lence, 54.

24 Müslim, "Sayd", 58, 60; Tirmizî, "Sayd”, 9; Nesâî, "Dahâya”, 41.
} 
kendisinin de cehenneme gitmesine yol açabileceği belirtilir. Belki de bugün kullandığımız "şeytan doldurur" ifadesi buradan gelmektedir.

Hz. Peygamber'in bu konuda başka uyarıları da söz konusudur. Allah Resûlu yanında (temrenleri meydanda) okları olan birisinin Mescid-i Nebevî́den geçtiğini görmüş ve "Temrenlerinden tut (da kimseye dokunmasınlar)" demiştir. Bu mealde diğer bir hadisinde de "Her kim mescidlerimizin, yahud çarşılarmmıın birinden (yanında) ok varken geçecek olursa eliyle temrenlerinden tut(up öyle geç)sin ki, bir Müslümanı yaralamasın." buyurmuştur. ${ }^{25}$

Anlaşıldığı üzere bu dönemde okçuluk her Müslüman'ın uğraşması gereken önemli bir vazife olarak vurgulanırken, diğer taraftan bununla ilgili olarak sosyal hayata dair birtakım düzenlemeler de yapılmıştır.

\section{HZ. PEYGAMBER'INN YAYLARI}

Ticaretin Arap Yarımadası'nda güçlü olması ve özellikle Mekke'de yaşayan Kureyşliler'in Yemen, Habeşistan, Suriye, Mısır ve İran'la olan kuvvetli ticari bağlantıları dolayısıyla bu bölgenin silah noksanlığı çekmediği anlaşılmaktadır. Mekke'deki evlerin depolarının, sürekli ithal edilen yeni silahlara ile dolduğu belirtilmektedir. Diğer taraftan Mekke'de mahalli olarak silah üretiminin de yapıldığı dikkat çekicidir. Zira Hz. Peygamber'in sahabesinden Habbâb b. Eret'in Mekke'de demircilik mesleğiyle uğraşıyor olması bu bağlamda önemlidir. ${ }^{26}$

David Nicolle, İslamiyet'in ilk on yılları boyunca Arap kılıçları üstündeki en önemli dış etkinin Hint teknolojisi olduğunu, erken İslâm döneminden günümüze ulaşabilen k1lıçların -her ne kadar özdeşleştirildikleri tarihi şahsiyetlerle olan bağları şüpheli olsa da- ${ }^{27}$ erken dönemlerde imal edilmiş olduklarını söylemektedir. ${ }^{28}$ Arapların tüccar bir toplum olduğu düşünülecek olursa, bu savaş teçhizatlarının bir şekilde Arap pazarlarına nasıl geldiği anlaşılmaktadır. Hz. Peygamber'in, Sa'îd b. Zeyd'i kendisine silah alması için Necd'e göndermesinden de yarımadadaki Necd gibi bazı bölgelerde silah üretiminin ya da bir silah pazarının olduğu sonucunu çıkarabiliriz. ${ }^{29}$

Bunları belirttikten sonra David Nicolle erken İslâm okçuluğunun, Bizans metotlarını takip etmiş olma ihtimalinin üzerinde durmakta ve bunun şaşırtıcı olduğunu söylemektedir. ${ }^{30} \mathrm{Bu}$ da Suriye ve Anadolu üzerinden ok ve yay malzemesinin Arap Yarımadası'na intikal ettiği, dönemin okçuluk bilgisinin buraya kadar ulaştığı anlamına gelmektedir.

Hz. Peygamber'in sahip olduğu silahların kaynağı olarak başta Bedir Savaşı'nda elde edilen ve kendi şahsina düşen silahlar olmak üzere Benî Kaynukâ' Gazvesi'nden elde edilen ganimetlerin olduğu gösterilmektedir. Hicrî 2. (624) yılda meydana gelen bu gazve sonrasında Hz. Peygamber'in payına üç mızrak, üç kılıç, üç yay ve iki zırh (Soğdiyye ve Fıdda denilen) düşmüştü. “Beydâ (beyaz)”

25 Zebîdî, Sahîh-i Buhârî Muhtasarı, 2/394.

26 Bk. M. Yaşar Kandemir, "Habbâb b. Eret", Türkiye Diyanet Vakfi İslâm Ansiklopedisi (İstanbul: TDV Yay., 1996), 14/340-341.

27 Topkapı Sarayı Mukaddes Emanetler Dairesi'nde teşhir edilen kılıçların Hind kılıcı olduğu belirtilmektedir. Bk. David Nicolle, İslam Orduları (600-1100), çev. Emir Yener (İstanbul: Türkiye İş Bankası Kültür Yay., 2013).

28 Nicolle, Isslam Orduları, 9, 15.

29 Bk. Muhammed Abdülhay el-Kettânî, et-Terâtibü'l-İdâriyye: Hz. Peygamber'in Yönetiminde Sosyal Hayat ve Kurumlar, çev. Ahmet Özel (İstanbul: İz Yay., 1991), 2/103.

${ }^{30}$ Nicolle, İslam Orduları, 9. 
ve "safrâ" isimli yayların kayın ağacından olduğu ifade edilirken, "Revhâ" adlı yayın cinsi ise belirtilmemektedir. ${ }^{31} \mathrm{~Hz}$. Peygamber'in ok atarken çıkardığ1 sesten dolayı "ketûm" olarak da isimlendirilen safrâ adlı yayının Uhud Savaşı'nda kırıldığı burada zikredilmelidir. ${ }^{32}$

David Nicolle, Hz. Peygamber'in Topkapı Sarayı'nda bulunan ve ona atfedilen yayının bambu yay olduğunu belirtmekte, 33 "kavs-1 saadet, kemân-1 Peygamberî" denilen bu yayın $118 \mathrm{~cm}$. uzunluğunda, kamış cinsinden tek parça olarak yapılmış olduğunu nakletmektedir. ${ }^{34}$

Hind bölgesinden gelen bambu yayların dışında Araplar'ın tek ahşabın yanı sıra iki ahşabın birleştirilmesiyle meydana getirilen, sinir ve boynuzla güçlendirilmiş yaylar da kullandıkları bilinmektedir. Bunlardan ilk ikisinin daha çok bedeviler, üçüncüsünün ise yerleşik halk tarafından tercih edildiği ifade edilmektedir. ${ }^{35}$ Bambu yayların aslında iki ahşabın, boynuzla birleştirilmesinden oluşan kompozit yaylardan güçlü olmadıkları burada hatırlatılmalıdır.

\section{HZ. PEYGAMBER DÖNEMİ SAVAŞLARI'NDAN OKÇULUKLA İLGİLI BAZI KESITTLER}

Hz. Muhammed'in yirmili yaşlarında Ficâr Savaşı'na iştirak ettiğinden ve konumuzla ilgili olarak Bedir Savaşı'ndan yukarıda bahsetmiştik. Burada bu ikisi dışındaki seriyyelerinden ve gazvelerinden fazlaca detaya girmeden, konumuzla alakalı olarak bazı hususları dile getirmek istiyoruz. Zira zikrettiğimiz bu seriyye ve gazvelerde okçuluğun önemli bir yere sahip olduğu görülmektedir.

\subsection{Ubeyde b. el-Hâris'in Râbiğ'a Seriyyesi}

Hicretin 8. ayında Ebû Süfyan'a karşı tertip edilen bu seriyyede ilk olarak Sa'd b. Ebî Vakkâs, sadağından çıkardığı okları düşmanın üzerine gönderdi. Vakidî onun İslâmî dönemde ilk defa ok atan kişi olduğunu söylemektedir. Attığı her okun mutlaka isabet ettiği ve o gün onun 20 ok attığ1 belirtilmektedir. O gün Sa'd'ın attığı okların dışında herhangi bir çatışma ortamına girilmediği de nakledilmektedir. ${ }^{36}$

\subsection{Nahle Seriyyesi}

Hicretten 17 ay sonra, Receb ayında Abdullah b. Cahş'ın komutasında bir seriyye Nahle'ye ulaşmıştı. Denildiğine göre Receb ayının son günü ya da Şaban'ın ilk günü idi. Nahle mevkiinde Müslümanlar, Amr b. el-Hadramî, el-Hakem b. Keysân el-Mahzûmî gibi şahsiyetlerin de içinde bulunduğu bir kervan gördüler. Haram aya girilip girilmediği tartışması sonrasında bu kervana saldırıp ganimet elde etme fikri ağır basınca, Vâkıd b. Abdillah, grubu savaşa teşvik ederek yayını

\footnotetext{
31 İbn Sa'd, Tabakât, 1-2/ 240; İbn Sa'd, Tabakât, çev. Musa Kazım Yılmaz vd., 1/472.

32 İbn Sa'd, Tabakât, 1-2/264; İbn Sa'd, Tabakât, çev. Musa Kazım Yılmaz vd., 2/27.

${ }^{33}$ Nicolle, İslam Orduları, 16.

34 Bozkurt, "Ok", 33/333. Mukaddes emanet anlayışının daha Emevîler döneminde -belki de daha önce- ortaya konulduğu görülmektedir. İbn A'sem, Halife Hişâm b. Abdilmelik'in hazineden Bedîr savaşında Müslümanların kullandığı mızraklardan birisinin getirilmesini emrettiği ve getirilen bir mızrağı Hazarlar'la savaş için gönderilen Saîd b. Amr el-Hareşî isimli bir komutana teberrüken (mübarek görme, uğurlu sayma) verdiği ifade edilmektedir. Bk. Ebû Muhammed Ahmed b. İbn A'sem el-Kûfî, Futûh (Beyrut: y.y., 1986), 7$8 / 270$.

35 Bozkurt, "Ok", 33/333.

${ }^{36}$ Vâkıdî, Hz. Peygamber'in Savaşları, 1/56, 57.
} 
hareket ettirip attığı her ok ile kervandakilere üstünlük sağladı. Nihayetinde Amr b. el-Hadramî Vâkıd'ın attığı okun isabet etmesiyle öldü. Böylece birkaç kişi esir alınarak kervan da ele geçirilmiş oldu. ${ }^{37}$

\subsection{Uhud Savaşı $(3 / 625)$}

Okçuların savaşın kaderini değiştirdiği Uhud Gazvesi, Hz. Peygamber döneminin önemli olaylarından birisidir. Bu savaşta Hz. Peygamber'in toplamda 700 askeri vardı. 50 kişiden oluşan bir okçu kuvvetini de piyadelerin arkasına, Ayneyn Tepesi'ne yerleştirdi ve komutanlığını da Abdullah b. Cübeyr'e verdi. 38

$\mathrm{Bu}$ okçulara da yerlerini hiçbir suretle bırakmamalarını, hattâ düşman bozulsa bile, mevkilerinden hiçbir tarafa ayrılmamalarını tekrar tekrar tenbîh etti. Müslümanların piyade kuvvetine arkadan herhangi bir baskın yapılmaması için okla kendilerini müdafaa etmelerini emretti. ${ }^{39}$ David Nicolle "...okçular müsadim (müsademe eden, çarpışan, vuruşan) vazifeden başka piyadenin kanatlarm düşman süvarisinden korumaktan da sorumluydular." demekle,40 bu savaşta okçuların mühim rolüne dikkat çekmektedir.

Tabii olarak savaşın ilk etabını Müslümanlar kazanmıştı. Müşrikler kaçarlarken Ayneyn Tepesi'ndeki okçular mevzilerini bıraktılar. Hâlid b. Velîd komutasındaki Kureyşli süvari birliği Ayneyn Tepesi'nin arkasından gelerek düşmanı takibe koyulan Müslüman piyadesini vurdu. İki ateş arasında kalmamak için bu kez Müslümanlar, çatışmanın olduğu Kanât Vadisi'nden Uhud Dağı'na doğru çekilmeye başladılar. ${ }^{41}$

Sa'd b. Ebî Vakkâs'tan gelen bir rivayette kendisinin; “Uhud günü Resulullâh (sav) ok kabindaki okları çıkarıp bana verirdi de: Ey Sa'd! Babam, anam sana kurban olsun, at! derdi." dediği nakledilmektedir.

Uhud günü Sa'd b. Ebî Vakkâs gibi en isabetli kemankeşlerden birisi de Ebû Talha idi. Uhud Savaşı'nda Resulullâh'ın yanından sahabe dağıldı̆̆ı zaman Ebû Talha, Resulullâh'ın hemen yanında kendi kalkanını ona siper yaparak ayrılmadı. Aynı zamanda Ebû Talha yayını çok sert çeken bir atıcıydı. Onun Uhud günü iki ya da üç yay kırdığı zikredilmektedir. Yanından ok dolu (ca'be) kubur

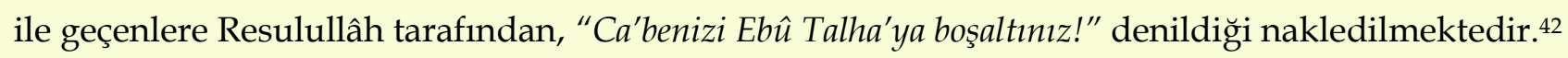

Sa'd b. Ebî Vakkâs ile Ebû Talha'nın dışında Uhud Savaşı' nda yer alan ve okçulukla şöhret bulmuş isimleri Vâkıdî'nin rivayetinden öğrenmekteyiz. O, Hz. Peygamber'in okçu ashabının isimlerini; Sâib b. Osman b. Maz'ûn, el-Mikdât b. Amr, Zeyd b. Hârise, Hâtıb b. Ebî Belte'a, Utbe b. Gazvân,

37 Vâkıdî, Hz. Peygamber'in Savaşlarn, 1/59-61; İbn Sa'd, Tabakât, çev. Musa Kazım Yılmaz vd., 2/2-3.

38 Uhud savaşı hakkında geniş bilgi için bk. Muhammed İbn İshâk, Hz. Peygamber' in Hayatı ve Gazveler (Kitâbü'sSiyer ve'l-Meğâzzî), çev. Ali Bakkal (İstanbul: İlk Harf Yay., 2013), 428-447; Vâkıdî, Hz. Peygamber'in Savaşları, 1/251-386; İbn Sa'd, Tabakât, çev. Musa Kazım Yılmaz vd., 2/35-48.

${ }^{39}$ Vâkıdî, Hz. Peygamber'in Savaşları, 1/280-281; İbn Sa'd, Tabakât, çev. Musa Kazım Yılmaz vd., 2/39.

${ }^{40}$ Nicolle, İslam Orduları, 14.

${ }^{41}$ Savaşın yapıldığı mekan ve okçuların stratejik konumları ile ilgili olarak geniş bilgi için bk. Fatih Erkoçoğlu, "Tarih-Mekan İlişkisi: Uhud Savaşı'nın Mekanı Üzerine Bazı Mülahazalar", Cumhuriyet Üniversitesi İlâhiyat Fakültesi Dergisi 15/1 (2011), 319-350.

${ }^{42}$ Vâkıdî, Hz. Peygamber'in Savaşları, 1/293; Zebîdî, Sahîh-i Buhârî Muhtasarı, 10/196. 
Hırâş b. es-Sımne, Kutbe b. Âmir b. Hadîde, Bişr b. el-Berâ b. Ma'rûr, Ebû Nâile Silkân b. Selâme, Âsım b. Sâbit b. Ebü'l-Aklah, Katâde b. en-Nu'mân ve Sehl b. Huneyf olarak vermektedir. ${ }^{43}$

Kanât Vadisi'nde, Ayneyn Tepesi önünde vuku bulan Uhud Savaşı'nın sonucunu okçular tayin etmiştir. Savaşın başında galip olan Müslümanlar, müteakiben okçuların stratejik mevkilerini terk etmeleri üzerine yenilmişlerdir. Daha önce zikredildiği üzere Abdullah b. Cübeyr en-Nu'mân elEnsârî, Uhud Savaşı'nda Ayneyn Tepesi'ne konuşlanan okçuların komutanı idi. Abdullah b. Cübeyr, ganimet için giden okçuları engellemeye çalışmış, fakat muvaffak olamamıştır. Kendisi orada Müşrikler tarafından şehit edilmiştir. ${ }^{44}$

\subsection{Hendek (Ahzâb/Müttefikler) Savaşı (5/627)}

Hendek Harbi ya da daha doğru ifade ile muhasarası 27 gün sürmüştü. Bu süre zarfında meydan harbi yapılmadı ve yapılamadı. Yalnız karşılıklı ok atmakla vakit geçirildi. Hendeği geçmeye teşebbüs eden düşman kuvvetleri okla karşılanıyordu. Burada ok ve yay silahının ne kadar önemli olduğu fark edilmektedir. Bu müdafaa harbinde Müslümanlar beş şehit vermişlerdi. Ensâr'ın reisi Sa'd b. Muaz bir ok isabetiyle kolundan yaralanmıştı. Atılan ok onun kolundaki damara isabet edince, akan kan bir türlü durdurulamamış, sahabi şehit olmuştu. 45

\subsection{Müreysi Gazvesi}

Hicrî 5 (627) yılında Benî Mustalik kabilesi üzerine düzenlenen bu gazvede Müslümanların, bir saat boyunca Benî Mustalik'e ok atışı gerçekleştirdikleri, ardından Hz. Peygamber'in emriyle tek bir adamın saldırışı gibi saldırıp düşmanı yenilgiye uğrattıkları nakledilmektedir. ${ }^{46} \mathrm{Bu}$ gazve ile $\mathrm{Hz}$. Peygamber'in savaşlarda özellikle nasıl bir saldırı nizamını uyguladığını öğrenebilmekteyiz. Ok atışlarının düşman nezdinden etkili olduğu, nihayetinde tek bir hamle ile düşmanın hezimete uğratıldı̆̆ $\mathrm{bu}$ rivayetten anlaşılmaktadır.

\subsection{Zûu-Kared (Kuyusu) ya da el-Ğâbe Gazvesi}

Gatafan ve Fezâre çapulcuları, Medine'nin kuzeyinde bulunan Ğâbe denilen ormanlık alana kadar geldiler ve Hz. Peygamber'in sağmal develerini alıp götürdüler. Rivayete göre develerin başında bulunan Ebû Zerr'in oğlu öldürülmüş, karısı da esir edilmiştir. İbn Ekva' isimli sahabi durumu haber alınca develeri kimin götürdüğünü sormuş, olaya şahit olan gençlerden birisi ise Gatafan ve Fezâre kabilerinin adamları olduğunu söylemiştir. İbn Ekva' gür sesiyle üç defa "Ey sabahçılar, erken kalkanlar; yetişin baskın var!" diye haykırmış. Sonra da İbn Ekva' baskını yapanları yaya olarak süratle takibe koyulmuş, onlara Zû-Kared Suyu başında yetişmişti. İbn Ekva' bunlara ok atmağa ve her ok attıkça da: "Alınız alçaklar, iyi biliniz ki, ben İbn Ekva'ım, bu gün alçakların öleceği gündür!" diye haykırmağa başlamış ve fitraten kuvvetli sesiyle ve herkesçe malum şecaatiyle saldırganları korkutmuştur. O, kırk kişilik süvari birliğini, su içmelerine bile fırsat vermeden kaçırıp develeri de kurtarmıştır.

43 Vâkıdî, Hz. Peygamber'in Savaşları, 1/294, 303.

${ }_{44}$ İbn Sa'd, Tabakât, çev. Musa Kazım Yılmaz vd., 2/41; bk. Ebû'l-Fazl Ahmed b. Ali el-Askalânî, el-İsâbe fì temyîzi's-sahâbe (Beyrut: y.y., 2004), 750.

45 Vâkıdî, Hz. Peygamber'in Savaşları, 2/86-145; İbn Sa'd, Tabakât, çev. Musa Kazım Yılmaz vd., 2/66-75; Zebîdî, Sahîh-i Buhârî Muhtasarı, 10/219.

${ }^{46}$ Vâkıdî, Hz. Peygamber'in Savaşları, 2/52; İbn Sa'd, Tabakât, çev. Musa Kazım Yılmaz vd., 2/64-65. 
Develeri önüne katarak Medine' ye yöneldiğinde ise yolda Hz. Peygamber'in maiyyetinde beş yüz kişilik askeri birlikle karşılaşmış, İbn Ekva' Hz. Peygamber'e eşkiyanın halen su başında olabileceğini bunların üzerine bir müfreze gönderildiğinde onların tepelenebileceğini söylemişse de Hz. Peygamber; "Ey İbn Ekva', sen alacağını aldın ve yalnız başına onları yendin. Artık onlardan vaz geç!. Hem onlar şimdiye kadar çoktan yurtlarnna varmışlardır!" buyurup takibat yaptırmamıştır. İbnü'lEkva'ya bir iltifat olarak onu kendi devesine bindirmiş, Medine'ye kadar da onunla yolculuk etmiştir. ${ }^{47}$

İbnü'l-Ekva'ın bu yaşadığı, iyi bir okçunun tek başına neler yapabileceğine dair çok güzel bir örnek olmalıdır. Tabi ki olayın vukûunda İbnü'l-Ekva'nın çağrısıla bir Müslüman birliği hazırlanıyor olmalıdır, fakat onun kararlığının yanında iyi ok atışının düşmanı ürküttüğü ve onları arkasına bakmadan kaçırdığı anlaşılmaktadır. Ayrıca İbnü'l-Ekva'ın düşmanı epeyce bir süre takip ettiği de bu rivayette ortaya çıkmaktadır.

\subsection{Hudeybiye Musalahasi 6/628}

Hicretin 6. yılının Zilka'de ayında Hz. Peygamber, rüyasında Kâbe'yi tavaf ettiğini görmüş, bunun üzerine de umre yapmaya karar vermişti; “Andolsun, Allah, Elçisi'nin rüyasını doğru çıkardı. (Allah'ın elçisi, rüyada ashabıyla birlikte Mekke'ye girdiklerini, bazılarının saçların tamamen traş ettiklerini, bazılarının da kısalttığını görmüştü.) Allah dilerse güven içinde (kiminiz) başlarınızı traş ederek ve (kiminiz saçlarınıı) kısaltarak, korkmadan Mescid-i Harâm'a gireceksiniz. Allah sizin bilmediğinizi bildi, bundan önce, size yakın bir fetih (Hayber fethini) verdi." 48

Hz. Peygamber yedi yüz ila bin beş yüz kişilik bir grupla yola çıktı. Bu kişilerin yanlarında kınlarında olan kılıçlarından başka silah bulunmamaktaydı. Bu topluğun niyeti sadece umre ziyareti idi. Hiçbir şekilde askeri hareket özelliği taşımamakla birlikte istişare sonucunda doğruca Kâbe'ye yürünmesi, engelleme olduğu takdirde de müşriklerle çarpışılması yönünde görüş beyan edildi. Bu arada Müşrikler, Müslümanların Mekke'ye saldırabilecekleri endişesini taşımaktaydılar. Hâlid b. Velid, iki yüz kişilik bir süvari birliği ile Müslümanların üzerine yürüdü. Ama Müslümanlar da ne mızrak ne de ok ve yay vardı. Üzerlerinde sadece kılıçlarının oluşu, onların dinî maksatla geldiklerini ve herhangi bir saldırı vukuunda bu kılıçların sadece kendilerini savunmaya yönelik olduklarını açık bir şekilde göstermektedir. Ayrıca yapılan antlaşma ile bir sonraki yıl gelirken de silahları kınlarında oldukları halde Mekke'ye girebileceklerdi. ${ }^{49}$

Müslümanların kılıçları kınlarında olduğu halde Mekke'ye gelişleri, yanlarında ok, yay ve mızrak gibi silahları bulundurmamaları, herhangi bir saldırganlık maksatlarının olmadığını kanıtıdır. Ok ve yay gibi silahlar her ne kadar birer savunma silahları gibi görünseler de burada gerçekte bir saldırı silahı olarak değerlendirildikleri anlaşılmaktadır.

\subsection{Huneyn Savaşı $(8 / 630)$}

\footnotetext{
${ }^{47}$ Vâkıdî, Hz. Peygamber' in Savaşları, 2/188-200; İbn Sa'd, Tabakât, çev. Musa Kazım Yılmaz vd., 2/82-86; Zebîdî, Sahîh-i Buhârî Muhtasarı, 10/255-257.

${ }^{48}$ el-Fetih $48 / 27$.

49 Vâkıdî, Hz. Peygamber'in Savaşları, 2/221-260; İbn Sa'd, Tabakât, çev. Musa Kazım Yılmaz vd., 2/97-108.
} 
Toplamda on iki bin kişiden oluşan Hz. Peygamber yönetimindeki İslam ordusu, Mekke'den hareketle Huneyn Vadisi'ne yönelmişti. Berâ b. Âzib'ten gelen rivayete göre ${ }^{50}$ iyi okçu oldukları anlaşılan, Mâlik b. Avf komutasındaki Hevâzin kabilesi savaşçlları burada Müslümanlara pusu kurmuşlardı. Bu pusu, Müslüman ordusunun ilk etapta geri çekilmesine ve hatta neredeyse bozguna uğramasına neden oluyordu. ${ }^{51}$ Nihayetinde Müslüman ordusu Hz. Peygamber'in çabalarıyla yeniden toparlanmış ve düşmanı yenilgiye uğratmıştır.

İyi okçulardan oluşan Hevâzin kabilesi, pusu kurdukları Huneyn bölgesinin dağlık arazilerden oluşmasının da yardımıyla İslam ordusunu hezimete uğratacak bir duruma gelmişlerdi. Tabi ki dağlık araziler stratejik bakımdan önemli mevkiler olmakla birlikte kaynaklarımızın Hevâzin kabilesi savaşçılarının iyi okçulardan oluştuğunu söylemesi, özellikle engebeli arazilerde okçuların etkin bir saldırı pozisyonu elde ettiklerini bize göstermektedir. Bunun gibi hususlar $\mathrm{Hz}$. Peygamber'in okçuluğa neden bu kadar fazla önem verdiğinin açık göstergesi gibidir.

\section{SONUÇ}

Mezopotamya mitolojisinde bir güç sembolü olarak görülen ok ve yay, en eski zamanlardan beri av ve savaş aleti olarak kullanılmıştır. Arap Yarımadası'nın çevresinde hakimiyet kuran ve varlıklarını sürdüren Asurlular, Mısırlılar, Orta Asya Kavimleri, Sâsânîler ve Doğu Roma bu silahı iyi kullanan savaşçıları ordularında istihdam etmişlerdir.

Arap Yarımadası'nın Hicâz bölgesinde Hz. Peygamber döneminde atıcılı̆̆ın öneminin fark edildiği, bilhassa ok ve yayın bu açıdan bu coğrafyada da kıymetli silahlar olduğu görülmektedir.

Hz. Peygamber döneminde okçuluğun durumu ile ilgili olarak hazırladığımız bu çalışmada özellikle seriyye ve gazvelerde karşılaştığı durumlar da göz önünde bulundurulduğunda kendisinin ok ve yay kullanımına büyük önem verdiği, özellikle bu silahın taşıdığı ehemmiyetin bizzat kendisinin de farkında olduğu anlaşılmaktadır. O'nun Bedir Savaşı'ndaki talimatı ve Medine'de muhtelif ortamlarda söylediği okçuluğu teşvik edici ifadeleri bu bağlamda önemlidir. Muvazzaf askerliğin henüz ortada olmadığı bir dönemde Medine'de inşa ettiği toplumunu, iç ve dış tehditlere karşı teyakkuz halinde tutmaya çalıştığı, onları her daim ok ve yay talimi yapmalarını teşvikinden anlaşılmaktadır.

\footnotetext{
50 Zebîdî, Sahîh-i Buhârî Muhtasarı, 8/316.
}

51 Vâkıdî, Hz. Peygamber'in Savaşları, 3/119-156; Zebîdî, Sahîh-i Buhârî Muhtasarı, 10/322-323. 


\section{KAYNAKÇA}

Bottero, Jean - Noah Kramer, Samuel. Mezopotamya Mitolojisi. çev. Alp Tümertekin. İstanbul: İş Bankası Kültür Yay., 2017.

Bozkurt, Nebi. Hadiste Folklor ve Ĕ̆lence. İstanbul: İFAV Yay., 1997.

Bozkurt, Nebi. "Ok". Türkiye Diyanet Vakfi İslâm Ansiklopedisi. 33/333-335. İstanbul: TDV Yay., 2007.

Dârimî, Ebû Muhammed Abdullah. Sünen. tlk. es-Seyyid Abdullah Hâşim Yemânî el-Medenî. 2 Cilt. İstanbul: y.y., 1992.

Ebû Dâvud, Süleyman b. el-Eş'as. Sünen, haz. Bedrettin Çetiner. 5 Cilt. İstanbul: y.y., 1992.

Erkoçoğlu, Fatih. “Tarih-Mekan İlişkisi: Uhud Savaşı'nın Mekanı Üzerine Bazı Mülahazalar”. Cumhuriyet Üniversitesi İlâhiyat Fakültesi Dergisi 15/1 (2011), 319-350.

Hamidullah, Muhammed. Hz. Peygamber'in Savaşları. İstanbul: y.y., 1991.

İbn A'sem el-Kûfî, Ebû Muhammed Ahmed. Futûh. 8 Cilt. Beyrut: y.y., 1986.

İbn Hacer, Ebû'l-Fazl Ahmed b. Ali el-Askalânî. el-İsâbe fî temyîzi's-sahâbe. Beyrut: y.y., 2004.

İbn Hişâm, Ebû Muhammed Abdülmelik b. Hişâm. es-Sîretü'n-nebeviyye. tlk. Ömer Abdüsselâm Tedmûrî. 4 Cilt. Beyrut: y.y., 1993.

İbn İshak, Muhammed. Hz. Peygamber'in Hayatı ve Gazveler (Kitâbü's-Siyer ve'l-Meğâzî). çev. Ali Bakkal. İstanbul: İlk Harf Yay., 2013.

İbn Sa'd, Muhammed b. Sad b. ez-Zührî. Tabakâtu'l-kübrâ. 8 Cilt. Beyrut: y.y., 1996.

İbn Sa'd, Muhammed b. Sad b. ez-Zührî. Kitâbü't-Tabakâti'l-Kebîr, Tabakât, Resûlullah'ın Kutlu Sîreti. çev. Musa Kazım Yılmaz vd. 11 Cilt. İstanbul: Siyer Yay., 2015.

Gökçek, L. Gürkan - Akyüz, Faruk. “Asur Ordusu". Tarih Araştırmaları Dergisi 32/54 (2013), 41-62.

Kandemir, M. Yaşar. "Habbâb b. Eret". Türkiye Diyanet Vakfi İslâm Ansiklopedisi. 14/340-341. İstanbul: TDV Yay., 1996.

Kettânî, Muhammed Abdülhay. et-Terâtibü'l-İdâriyye: Hz. Peygamber'in Yönetiminde Sosyal Hayat ve Kurumlar. çev. Ahmet Özel. 3 Cilt. İstanbul: İz Yay., 1991.

Koca, Feyzullah. "Antik Mısır'da Avcılık, Binicilik, Okçuluk ve Görsellerin Yorumlamaları". Uluslararası Sosyal Araştırmalar Dergisi 11/59 (2018), 1490-1497.

Müslim, Ebû'l-Hüseyin Müslim b. el-Haccâc b. Müslim el-Kuşeyrî. Sahîh. thk. Muhammed Fuâd Abdülbakî. 3 Cilt. İstanbul: y.y., 1992.

Nesâî, Ebû Abdurrahman Ahmed b. Şu'ayb. Sünen. haz. Bedrettin Çetiner. 8 Cilt. İstanbul: y.y., 1992.

Nicolle, David. İslam Ordularn -600-1100-. çev. Emir Yener. İstanbul: Türkiye İş Bankası Kültür Yay., 2013.

Nicolle, David. Doğu Roma Orduları -M. S. 306-886-. çev. Buket Bayrı. İstanbul: Türkiye İş Bankası Kültür Yay., 2013. 
Sarıçam, İbrahim. Hz. Muhammed'in Evrensel Mesajı. Ankara: DİB Yay., 2003.

Sivrioğlu, Ulaş Töre. "Sâsânîlerde Askeri Teşkilat, Silah Teknolojisi ve Savaş Stratejileri". Turkish Studies 8/5 (2013), 675-703.

Tirmizî, Ebû İsa Muhammed b. İsa b. Sevre. Sünen. haz. Bedrettin Çetiner. 4 Cilt. İstanbul: y.y., 1992.

Vâkıdî, Ebû Abdullah Muhammed b. Ömer. Hz. Peygamber'in Savaşları (Kitâbü'l-Meğâzî̀). çev. Musa K. Yılmaz. 3 Cilt. İstanbul: İlk Harf Yay., 2007.

Zebîdî, Zeynüddin Ahmed b. Ahmed. Sahîh-i Buhârî Muhtasarı (Tecrid-i Sarîh Tercemesi ve Şerhi). çev. Ahmed Naim. Ankara: y.y., 1983. 